\title{
Evaluation of Fat and Vitamin E in Some Baby Biscuit
}

\section{Ayman S Mazahreh*}

Professor, Al-BALQA Applied University and Prince Alia'a University College, Jordan

*Corresponding Author: Ayman S Mazahreh, Professor, Al -BALQA Applied

University and Prince Alia'a University College, Jordan.

DOI: $10.31080 /$ ASNH.2020.04.0643
Received: January 30, 2020

Published: February 11, 2020

(C) All rights are reserved by Ayman S

Mazahreh.

\section{Abstract}

This study aims to evaluate by analysis the following on three different products of baby biscuit from three different firms: Vitamin E, moisture fat, refractive index, free fatty acid (FFA), peroxide value (PO), iodine number, totox and P-anasidine, melting point, rancimat value of the fat extracted from the biscuits sample at the beginning, and the end of 6-month at-room temperature in wood cupboard.

At the beginning, and at the end the results were respectively as follows: the content of vitamin $\mathrm{E}$ which was $(3.79,2.88) \mathrm{in} \mathrm{mg} / 100$ $\mathrm{g}$ dry matter in the products from three different firms. Moisture percentages were $(4.0,5.25)$, FFA $(0.19,0.34)$, PO $(0.28,0.52)$, iodine number $(51.83,59.93)$, refractive index $(390.33,430.67)$, P-anasidine $(22.22,23.57)$, fat \% was (16.34), melting point was 24.4 . Rancimat value of the fat was 75.57, Saturated. F.A was 38.187 Unsaturated. F.A was 49.77, Trans SFA was 11.7, Totox $(22.77,24.61)$ were evaluated by calculation. It may be concluded that $24 \%$ of vitamin E were lost during the storage period.

Keywords: Vitamin E; Babe Biscuit; Storage Period; Antioxidants

\section{Introduction}

With the continuous advancements in the food industry in general and a child's nutrition care, the demand for ready to eat processed foods with better shelf life, satisfying taste, easiness of portability, and with high nutritional quality. We cannot deny that the increasing employment of women in the industry and the public sector arouses the need of special snacks and diet products to satisfy the requirements of these advancements [1]. Production of special baby biscuits was considered as an important advancement in the food industry because it has a high nutritive value [2]

Since Vitamin E (tocopherols and tocotrienols) is considered to be a potent antioxidant, it is essential for human nutrition because it has the ability to prevent oxidative damage to cell through inactivation of free radicals and reactive oxygen species [3]. Vitamin E serves as an important antioxidant role in cellular membranes by blocking the peroxidation of polyunsaturated fatty acid (PUFA) Consumption of foods rich in vitamin $\mathrm{E}$ may reduce the risk for epithelial cancers, heart disease and stork [4]. A daily intake of 3-15 $\mathrm{mg}$ of tocopherol is required on a normal diet. Amounts in excess of $15 \mathrm{mg}$ are probably needed when large amounts of unsaturated fatty acid are included in the diet [5].

\section{Materials and Methods}

Determination of vitamin E by Emmerie-Engel reaction [6] and Calorimetric of $\alpha$ - tocopherol was done by spectronic 20 calorimeter. Products were collected from three different firms at the production days all samples were performed in triplicate, immediately milled and under $\mathrm{N} 2$ gas packaged and stored in the dark $20^{\circ} \mathrm{C}$.
The vitamin E content was analyzed after six months of storage at room temperature in wood cupboard; one separate bag was taken out of storage on each occasion.

\section{Result and Discussion}

The results showed the average and standard deviation of the moisture, Vitamin E, refractive index, (FFA), (PO), iodine number, totox and P-anasidine, melting point, rancimat value, Saturated. F.A, Unsaturated. F.A, Trans SFA was of the fat extracted from the biscuits sample at the beginning, and the end of 6 month-at room temperature in wood cupboard, in three factories (Table 1).

Most determination of the total tocopherol content of foods are based upon the Emmerie-Engel reaction, Which involves the reaction of the tocopherols in the extract with ferric chloride to yield ferrous chloride.

The ferrous chloride reacts with alp1ha dipyridy1 to yield a red complex, which is measured calorimetrically. In this study Vitamin E was evaluated according to Emmerie-Engel reaction [6].

It is concluded from table number 1 that the content of Vitamin $E$ in the three products at the end of the storage period was decreased by $0.24 \%$. However, the moisture percentage in the same three products was increased by the end of the period by $31 \%$.

In the production of white wheat flour from whole grain wheat, the vitamin $\mathrm{E}$ content is reduced by about $50 \%$ due to the removal of bran and germ, this reduction of vitamin E content is not usually compensated for by fortification, as in the case of some of the 


\begin{tabular}{|l|l|c|c|c|c|c|}
\hline & & $\begin{array}{c}\text { Biscuit } \\
\text { firma } \\
\text { A }\end{array}$ & $\begin{array}{c}\text { Biscuit } \\
\text { firma } \\
\text { B }\end{array}$ & $\begin{array}{c}\text { Biscuit } \\
\text { firma C }\end{array}$ & Average & $\begin{array}{c}\text { Standard } \\
\text { deviation }\end{array}$ \\
\hline Moisture & $\begin{array}{l}\text { Moisture } \\
\text { before }\end{array}$ & 4.23 & 3.52 & 4.26 & 4.00 & 0.42 \\
\hline & $\begin{array}{l}\text { After at } \\
\text { room t }\end{array}$ & 4.88 & 5.33 & 5.54 & 5.25 & 0.34 \\
\hline Vite & $\begin{array}{l}\text { Vitamin } \\
\text { E Before }\end{array}$ & 3.29 & 3.93 & 4.14 & 3.79 & 0.44 \\
\hline & $\begin{array}{l}\text { After at } \\
\text { room t }\end{array}$ & 2.88 & 2.64 & 3.11 & 2.88 & 0.24 \\
\hline R. index & Before & 372 & 367 & 432 & 390.33 & 36.17 \\
\hline ffa & $\begin{array}{l}\text { After at } \\
\text { room t }\end{array}$ & 456 & 402 & 434 & 430.67 & 27.15 \\
\hline Before & 0.21 & 0.26 & 0.09 & 0.19 & 0.09 \\
\hline Peroxide & $\begin{array}{l}\text { Bfter at } \\
\text { room t }\end{array}$ & 0.46 & 0.44 & 0.12 & 0.34 & 0.19 \\
\hline Before & 0.34 & 0.11 & 0.38 & 0.28 & 0.15 \\
\hline Aodine & $\begin{array}{l}\text { After at } \\
\text { room t }\end{array}$ & 1.01 & 0.08 & 0.46 & 0.52 & 0.47 \\
\hline Before & 61.7 & 40.9 & 52.9 & 51.83 & 10.44 \\
\hline Fat & $\begin{array}{l}\text { After at } \\
\text { room t }\end{array}$ & 69.5 & 57.2 & 53.1 & 59.93 & 8.54 \\
\hline Melting & $\begin{array}{l}\text { After at } \\
\text { room t }\end{array}$ & 14.85 & 34.96 & 20.91 & 23.57 & 10.32 \\
\hline Rancimat & Before & 14.38 & 32.32 & 21.6 & 22.77 & 9.04 \\
\hline $\begin{array}{l}\text { After at } \\
\text { ated. F.A }\end{array}$ & 16.87 & 35.12 & 21.83 & 24.61 & 9.43 \\
\hline room t \\
rated. F.A
\end{tabular}

of vitamin $E$ in specific, as this study shows the decrease in vitamin E post the storage period. Tocopherols are quite commonly used for the stabilization of fats and fatty products against oxidation. A natural Tocopherols, a material derived from vegetable oil distillate additives, increases the vitamin content of finished products, which may - be an added incentive to snack diet- provide a natural source of vitamin E, and protect freshness of the snack diet especially for baby biscuit [8].

In general, high amounts of vitamin $\mathrm{E}$, have a protective effect on the polyunsaturated fats in biscuits. Vitamin E acts as a free radical scavenger, terminating the free radical reaction in autoxidation [9].

Within the observation on table number 1 , it is noted that the fat extracted from the biscuit factory $B$ has the highest fat percentage and the lowest vitamin $\mathrm{E}$ in comparison with the other two factories with the highest totox (highest fat oxidation). On the other hand, we observe that the fat extracted from the biscuit factory A has the lowest fat percentage, but has the highest vitamin $E$, the highest trans fatty acid, and the lowest totox (lowest fat oxidation), this concludes that factory A oil has the least deterioration. That means any fat that has the highest amount of vitamin $E$ and trans fatty acid has the highest degree of resistance to oxidation. It is well noted that, trans fatty acid has bad acid effect on heart health, which means we must not have a high trans fatty acid but we must have a high vitamin $\mathrm{E}$ content.

The biscuit manufacturer uses a wide range of ingredients of which the oils fats offer the highest potential risk of rancidity in the autoxidation of fats, unsaturated fatty acids are oxidized to hydro peroxides which on subsequent decomposition yield a number of saturated and unsaturated aldehydes and ketones. The oxidation of vitamin E prevents lipid oxidation especially of polyunsaturated fatty acids. Tocopherols are quite commonly used for the stabilization of fats and fatty products against oxidation. A natural Tocopherols, a material derived from vegetable oil distillate additives increases the vitamin content of finished products, which maybe an added incentive to baby biscuits provide a natural source of vitamin E for child's protecting child health [10] and protect freshness of the baby biscuit.

\section{Conclusion}

The result of this study showed that loss of Vitamin $\mathrm{E}$ during the storage of baby biscuit for 6 months in average $0.24 \%$, and with increase of moisture percentage in products during storage period. Specified amount of Vitamin E is recommended to be added to offset the effects off losses during storage, Vitamin $\mathrm{E}$ is powerful antioxidant in our bodies, and in our foods specially in fat and fatty foods.

\section{Bibliography}

1. Mazahreh Ayman S." Evaluation of Vitamin E and the Change in its Quality During the Storage Period of Some Cracker Product”. Medwell Journals, Journal of Food Technology 9 (2011): 95-98. 
2. Singh R., et al. "Nutritional Evaluation of Soy Fortified Biscuits". Journal of Food Science and Technology 37 (2000): 162164.

3. Chavan JK and Kadam SS. "Nutritional Enrichment of Bakery Products by Supplementation with Nonwhite Flours". Critical Reviews in Food Science and Nutrition 33 (1993): 189-226.

4. Mazahreh Ayman S. "The Effect of Storage Temperature on The Content of Vitamin E in Some Types of Biscuits and its Impact evidences on Oxidative Indicators". International Journal of Research in Agriculture and Food Sciences (2016).

5. J Lehmann., et al. "Vitamin E in Foods from High and Low Linoleic Acid Diets". Journal of the American Dietetic Association 86 (1986): 1208-1216.

6. AOAC. Official Methods and Recommended Practices of the Americal Oil Chemists Society (4th ed.), Firestone D. American Oil Chemists Society, Champaign IL, USA, Method Ca 5a40, Cd 8-53 (1990).

7. Wennermark BH and Jagerstad M. "Bread Making and Storage of Various Wheat Fractions Affect Vitamin E". Journal of Food Science 57 (1990): 1205-1209.

8. Al-Shawabkeh., et al. "Evaluation of Fat and Vitamin E in Some Cookies Diet”. Pakistan Journal of Nutrition 8.3 (2009): 214217.

9. Yusuf S. "Vitamins E supplementation and Cardiovascular Events in High - Risk Patients". The New England Journal of Medicine 20 (2000): 154-159.

10. Gaziano JM. "Antioxidants in Cardiovascular Disease: Randomized Trials". Nutrition Reviews 54.6 (1996): 175-177.

\section{Assets from publication with us}

- Prompt Acknowledgement after receiving the article

- Thorough Double blinded peer review

- Rapid Publication

- Issue of Publication Certificate

- High visibility of your Published work

Website: https://www.actascientific.com/

Submit Article: https://www.actascientific.com/submission.php

Email us: editor@actascientific.com

Contact us: +919182824667 